Article

\title{
Eco-friendly synthesis of high silica zeolite $Y$ with choline as green and innocent structure-directing agent
}

\author{
Dawei He a,b,†, Danhua Yuan a,†, Zhijia Song a,b, Yunpeng Xu a,*, Zhongmin Liu a,\# \\ a National Engineering Laboratory for Methanol to Olefins, Dalian National Laboratory for Clean Energy, Dalian Institute of Chemical Physics, Chinese \\ Academy of Sciences, Dalian 116023, Liaoning, China \\ b University of Chinese Academy of Sciences, Beijing 100049, China
}

\section{A R T I C L E I N F 0}

\section{Article history:}

Received 12 September 2018

Accepted 23 September 2018

Published 5 January 2019

\section{Keywords:}

Zeolite synthesis

FAU zeolite

High silica

Green organic structure-directing agent

(Hydro)thermal stability

\begin{abstract}
A B S T R A C T
Zeolite synthesis in contemporary chemical industries is predominantly conducted using organic structure-directing agents (OSDAs), which are chronically hazardous to humans and the environment. It is a growing trend to develop an eco-friendly and nuisanceless OSDA for zeolite synthesis. Herein, choline is employed as a non-toxic and green OSDA to synthesize high silica Y zeolite with $\mathrm{SiO}_{2} / \mathrm{Al}_{2} \mathrm{O}_{3}$ ratios of 6.5-6.8. The prepared $\mathrm{Y}$ zeolite samples exhibited outstanding (hydro)thermal stability at ultrahigh temperature owing to the higher $\mathrm{SiO}_{2} / \mathrm{Al}_{2} \mathrm{O}_{3}$ ratio. The XRF, SEM, ${ }^{29} \mathrm{Si}-\mathrm{NMR}$ and ${ }^{13} \mathrm{Na}+$ results suggested that choline plays a structure-directing role in the synthesis of Y zeolite, while the feed molar fraction of $\mathrm{Na}^{+}$is a crucial determinant for the framework $\mathrm{SiO}_{2} / \mathrm{Al}_{2} \mathrm{O}_{3}$ ratio and the crystal morphology.
\end{abstract}

(C) 2019, Dalian Institute of Chemical Physics, Chinese Academy of Sciences. Published by Elsevier B.V. All rights reserved.

\section{Introduction}

Zeolites have been extensively used as catalysts, adsorbents and ion-exchangers owing to their well-defined microporous structures, adjustable acidities and a large variety of available frameworks and chemical compositions [1-5]. Among the approximate reported 230 zeolite framework types, the vast majority of zeolites are synthesized in the presence of organic structure-directing agents (OSDAs), and more novel topologies are synthesized by the application of new OSDAs [6-8]. On the other hand, most common organic templates are quaternary ammonium or amines, which are usually unavailable or toxic or environmentally hazardous. Therefore, it is desirable to develop eco-friendly synthesis routes with the use of non-toxic and green OSDAs [9-11]. For example, polyquaternium-6, a typical component of shampoo, was successfully used as a template to synthesize EMT-rich faujasite, which offers the possibility of industrial applications of EMT zeolites [12]. However, it has been demonstrated that among a huge amount of organics, only a small minority of organics have the ability as structure-directing agents for zeolite synthesis. It is more difficult to find a non-toxic and eco-friendly OSDA with "fitting" size and shape for the targeted zeolite topology.

Herein we focus on the synthesis of $\mathrm{Y}$ zeolite with a 12-membered window size of $7.4 \AA$ and a supercage cavity size of $12 \AA$, which has been vastly used as the main active component of fluidized catalytic cracking (FCC) catalysts so far [13-18]. It has been demonstrated that increasing the frame-

$\uparrow$ These authors contributed equally to this work.

* Corresponding author. Tel: +86-411-84379518; Fax: +86-411-84379038; E-mail: xuyp@dicp.ac.cn

\# Corresponding author. Tel: +86-411-84379998; Fax: +86-411-84379038; E-mail: liuzm@dicp.ac.cn

The work was supported by the National Natural Science Foundation of China (Grant No.21802136).

DOI: 10.1016/S1872-2067(18)63167-5 | http://www.sciencedirect.com/science/journal/18722067 | Chin. J. Catal., Vol. 40, No. 1, January 2019 
work $\mathrm{SiO}_{2} / \mathrm{Al}_{2} \mathrm{O}_{3}$ ratio of $\mathrm{Y}$ zeolite is helpful to enhance its acid strength, (hydro)thermal stability and catalytic activity $[19,20]$. Whereas there has been a restricted upper limit for the $\mathrm{SiO}_{2} / \mathrm{Al}_{2} \mathrm{O}_{3}$ ratio of $\mathrm{Y}$ zeolite prepared by traditional OSDA-free synthesis routes [21]. Nowadays, the most widely employed zeolite $\mathrm{Y}$ in industry is ultra-stable zeolite $\mathrm{Y}$ (or USY, $\mathrm{SiO}_{2} / \mathrm{Al}_{2} \mathrm{O}_{3}$ ratio $>5$ ) prepared by post-treatments to remove framework aluminium [22]. The post-synthesis treatments include hydrothermal dealumination and treatment with chemicals, which cause environmental pollution and high energy consumption, and compromise the structural integrity of zeolite, owing to reduplicative calcination and chemical treatments [23-26] Compared with these post-treatments, one-step direct synthesis methods in the presence of OSDAs are beneficial for the synthesis of high silica Y zeolite with higher crystallinity and avoid lots of complicated physicochemical treatments.

Delprato et al. [27] firstly developed a one-step direct synthesis method for zeolite $\mathrm{Y}$ with $\mathrm{SiO}_{2} / \mathrm{Al}_{2} \mathrm{O}_{3}$ ratio of around 9 by employing crown ether (15-crown-5) as an OSDA in 1990. Inspired by crown ether, polyethylene oxides and tris(3,6-dioxaheptyl)amine, which are acyclic molecules containing $-\mathrm{OCH}_{2} \mathrm{CH}_{2}$ - groups similar to crown ether, were successfully used to synthesize zeolite $\mathrm{Y}\left(\mathrm{SiO}_{2} / \mathrm{Al}_{2} \mathrm{O}_{3}\right.$ ratio $\left.=6-7\right)$ [28]. In 2015, Xiao et al. [29] studied quaternary ammonium salts and synthesized high silica zeolite $\mathrm{Y}$ in the presence of $N$-methylpyridinium iodide. Our group used ethyl(or butyl)-3-methylimidazolium bromide and tetraethylammonium hydroxide as OSDAs for the synthesis of high silica zeolite $Y$ $[30,31]$. Nevertheless, the above OSDAs, especially crown ether, are expensive, toxic and environmentally unfriendly, which are unavailable for wide use in petrochemical processes. The development of an eco-friendly and "fitting" OSDA is difficult yet imperative to fill the gap in the synthesis of Y zeolite with the use of OSDAs.

Herein we focus on choline, a nontoxic, green and low-cost OSDA. Choline is a water-soluble vitamin-like essential nutrient that refers to quaternary ammonium salt containing $\mathrm{N}, \mathrm{N}, \mathrm{N}$-trimethylethanolammonium cation. Choline was first isolated by Adolph Strecker from animal bile [32]. Nowadays, choline is industrially produced at a few thousand tons per year by $100 \%$ atom economy process [33]. Choline has been employed as a structure-directing agent to synthesize zeolites such as ZSM-4, SSZ-13 and SAPO-5 [34-36]. In the present work, the synthetic methodology is rationally designed to use choline as an eco-friendly and nontoxic OSDA in the synthesis of high silica zeolite $\mathrm{Y}$ for the first time. The sample ChCl-Y is synthesized with choline chloride and $\mathrm{ChOH}-\mathrm{Y}$ is prepared with choline hydroxide. They both show good crystallinity and high framework $\mathrm{SiO}_{2} / \mathrm{Al}_{2} \mathrm{O}_{3}$ ratio. By contrast, different properties of $\mathrm{ChCl}-\mathrm{Y}$ and $\mathrm{ChOH}-\mathrm{Y}$ reveal to us the separate roles and relationship of $\mathrm{Na}^{+}$and OSDA+ in the synthesis of high silica Y zeolite. Both the products $\mathrm{ChCl}-\mathrm{Y}$ and $\mathrm{ChOH}-\mathrm{Y}$ show more outstanding high temperature thermal and hydrothermal stability, compared with conventional zeolite Y. Given the huge amount of zeolite $\mathrm{Y}$ used worldwide as adsorbents and FCC catalysts, the ability to enhance the $\mathrm{SiO}_{2} / \mathrm{Al}_{2} \mathrm{O}_{3}$ ratio via the use of choline as an eco-friendly and economically viable OSDA would have a significant impact on the (petro)chemical industry and would be a great progress.

\section{Experimental}

\subsection{ChCl-Y preparation}

Firstly, $3.41 \mathrm{~g}$ choline chloride ([choline]Cl, Aladdin Chemical), 2.00 g sodium metaaluminate $\left(\mathrm{NaAlO}_{2}\right.$, Sinopharm Chemical) and 1.95 g sodium hydroxide ( $\mathrm{NaOH}$, Sinopharm Chemical) were dissolved in $26.65 \mathrm{~g}$ deionized water and stirred until a clear solution. Next, $24.60 \mathrm{~g}$ of silica sol $\left(\mathrm{SiO}_{2} 29.8 \%\right.$ aq. solution, Qingdao Ocean Chemical) was added in the above clear solution with strong agitation. The final gel was prepared with molar composition of $1.0 \mathrm{NaAlO}_{2}: 5.0 \mathrm{SiO}_{2}: 2.0 \mathrm{NaOH}$ : 1.0 [choline] $\mathrm{Cl}: 100 \mathrm{H}_{2} \mathrm{O}$. The mixture was stirred for $12 \mathrm{~h}$ at ambient temperature and maintained in ovens at $110{ }^{\circ} \mathrm{C}$ for 10 d. Calcined sample $\mathrm{ChCl}-\mathrm{Y}$ was obtained after calcination at 550 ${ }^{\circ} \mathrm{C}$ for $4 \mathrm{~h}$.

\subsection{ChOH-Y preparation}

Firstly, 6.60 g choline hydroxide ([choline] $0 \mathrm{H}, 45 \%$ aq. solution, Acros Organics), $2.00 \mathrm{~g} \mathrm{NaAlO}_{2}$ and $0.98 \mathrm{~g} \mathrm{NaOH}$ were dissolved in $23.00 \mathrm{~g}$ deionized water with stirring to form a clear solution. Next, $24.60 \mathrm{~g}$ silica sol was mixed with the above solution with strong agitation for $12 \mathrm{~h}$ at ambient temperature. $\mathrm{ChOH}-\mathrm{Y}$ was synthesized in stainless steel autoclaves at the crystallization temperature of $110{ }^{\circ} \mathrm{C}$ for $12 \mathrm{~d}$, with molar composition of $1.0 \mathrm{NaAlO}_{2}: 5.0 \mathrm{SiO}_{2}: 1.0 \mathrm{NaOH}: 1.0$ [choline] $\mathrm{OH}$ : $100 \mathrm{H}_{2} \mathrm{O}$. Calcined sample ChOH-Y was obtained after calcination at $550{ }^{\circ} \mathrm{C}$ for $4 \mathrm{~h}$.

To investigate the role of choline in the synthesis of zeolite $\mathrm{Y}$, the sample $\mathrm{Na}-\mathrm{Y}$ was designed as a reference sample with a composition of $1.0 \mathrm{NaAlO}_{2}: 5.0 \mathrm{SiO}_{2}: 2.2 \mathrm{NaOH}: 100 \mathrm{H}_{2} \mathrm{O}$. Na-Y sample was synthesized at $100{ }^{\circ} \mathrm{C}$ with a reaction time of $14 \mathrm{~d}$.

\subsection{Characterization of zeolites}

The X-ray diffraction (XRD) patterns were acquired using a PANalytical X'Pert PRO X-ray diffractometer using $\mathrm{Cu}-K_{\alpha}$ radiation with $\lambda=1.54059 \AA$, operating at $40 \mathrm{kV}$ and $40 \mathrm{~mA}$. The samples were scanned at $12^{\circ} / \mathrm{min}$ between $2 \theta$ angles of $5^{\circ}-65^{\circ}$. Scanning electron microscopy (SEM) images were collected with a Hitachi SU8020 scanning electron microscopy. $\mathrm{N}_{2}$ adsorption-desorption isotherms of the samples were measured at $-196{ }^{\circ} \mathrm{C}$ on a Micromeritics ASAP 2020 system. The solid state ${ }^{29} \mathrm{Si}-\mathrm{NMR}$ and ${ }^{27} \mathrm{Al}-\mathrm{NMR}$ experiments were conducted on a Bruker AvanceIII spectrometer equipped with a $14.1 \mathrm{~T}$ wide-bore magnet. TG-DSC measurement was conducted on a TA Q-600 analyzer with a heating rate of $10^{\circ} \mathrm{C} / \mathrm{min}$ from ambient temperature to $1100{ }^{\circ} \mathrm{C}$ in an air flow of $100 \mathrm{~mL} / \mathrm{min}$. The organic elemental composition of samples was measured by elemental analysis on an Elementar vario EL cube elemental analyzer. The chemical composition of the samples was calculated with a Philips Magix-601 X-ray fluorescence (XRF) spectrometer. Inductively coupled plasma optical emission spec- 
trometry (ICP-OES) analysis was conducted with a PerkinElmer 7300DV.

\section{Results and discussion}

\subsection{Results of ChCl-Y and ChOH-Y prepared with variational $\mathrm{OH}^{-}$concentrations}

The XRD patterns of the as-synthesized products $\mathrm{ChCl-Y}$ and ChOH-Y are respectively shown in Fig. $1 \mathrm{~A}$ and Fig. 1B. The $\mathrm{X}$-ray diffraction peaks with a high intensity are in agreement with the typical topological features of theoretical FAU framework. It indicates that $\mathrm{Y}$ zeolites with good crystallinity are synthesized by employing [choline]Cl or [choline]OH as an OSDA. The crystal morphologies of ChCl-Y and ChOH-Y are entirely different in SEM micrographs (Figs. 1C, 1D and S1). ChOH-Y exhibits uniform cubic octahedral crystals, and ChCl-Y shows spherical agglomerates with superficial triangle cone. It is reported that the crystal morphologies are affected by some experimental factors, for examples, the species of structure-directing agents and the special silica source or aluminium source [37-39]. The relationship between the dramatically different morphologies and the crystallization curves of $\mathrm{ChOH}-\mathrm{Y}$ and $\mathrm{ChCl}-\mathrm{Y}$ has aroused our attention. The crystallization curves of ChCl-Y and ChOH-Y samples are presented in Fig. $1 \mathrm{E}$ and $1 \mathrm{~F}$ wherein the relative crystallinity changes with various reaction time. The relative crystallinity is estimated by the reflection intensities of the X-ray diffraction peaks (1 111 ), $\left(\begin{array}{ll}2 & 2\end{array}\right.$ 0) and ( $\left.\begin{array}{lll}3 & 3 & 1\end{array}\right)$ of the samples. Both the crystallization curves of ChCl-Y and ChOH-Y exhibit typical S-shaped curves, which indicate that the crystallization process of $Y$ zeolite is comprised of induction period, continuous growth period and stable crystallization period. The induction period of ChOH-Y is $6 \mathrm{~d}$, which is longer than that ( $4 \mathrm{~d}$ ) of ChCl-Y. The crystallization of zeolite $\mathrm{Y}$ from $\mathrm{ChOH}-\mathrm{Y}$ is completed within $12 \mathrm{~d}$, which is also longer than that (9 d) of ChCl-Y. It is concluded that $\mathrm{ChCl}-\mathrm{Y}$ has a faster generation rate and faster growth rate compared with ChOH-Y.

As the synthesis process and the composition of ChCl-Y and $\mathrm{ChOH}-\mathrm{Y}$ are shown above, ChCl-Y and $\mathrm{ChOH}-\mathrm{Y}$ are designed with the same feed molar ratio of [choline] ${ }^{+}$and $\mathrm{OH}^{-}$. However, the sample $\mathrm{ChCl}-\mathrm{Y}$ is synthesized with $\mathrm{Na}^{+} / \mathrm{SiO}_{2}$ feed ratio of 0.6 , which is higher than that of $\mathrm{ChOH}-\mathrm{Y}(0.4)$ in the starting gels. Therefore it means that the change of $\mathrm{Na}^{+}$feed molar ratio has a major influence on zeolite morphologies and crystallization process. $\mathrm{Na}^{+}$is proposed to coordinate water molecular with subsequent displacement by silicate and aluminate species to form aluminosilicate microorganization, or further nucleation centers in the synthesis of zeolites. Therefore, higher $\mathrm{Na}^{+}$molar ratio of the starting gels contributes to shortening the crystallization time and improving the nucleation rate which trends to the agglomerates of small cubic octahedral crystal.

The $\mathrm{N}_{2}$ adsorption-desorption isotherms of calcined and as-synthesized samples are respectively shown in Fig. 2A and Fig. 2B. Calcined samples ChCl-Y and ChOH-Y exhibit a typical type-I adsorption-desorption isotherm, indicating that they are mainly consisted of very uniform micropores. The BET specific surface area, $t$-plot micropore area and pore volume of the samples are listed in Table S1. The BET specific surface area of the calcined samples ChCl-Y and ChOH-Y are 735.2 and 730.7 $\mathrm{m}^{2} / \mathrm{g}$, respectively, which are slightly larger than that $(694.1$ $\mathrm{m}^{2} / \mathrm{g}$ ) of Na-Y. The $t$-plot micropore area of ChCl-Y and ChOH-Y are 679.0 and $675.9 \mathrm{~m}^{2} / \mathrm{g}$, which indicates the presence of abundant micropores in the synthetic samples $\mathrm{ChCl}-\mathrm{Y}$ and ChOH-Y. The large BET specific surface area and uniform micropore property demonstrated that the use of choline choride and choline hydroxide is helpful to the formation of micropore structure.

As shown in Fig. 2A and Fig. 2B, BET specific surface area of

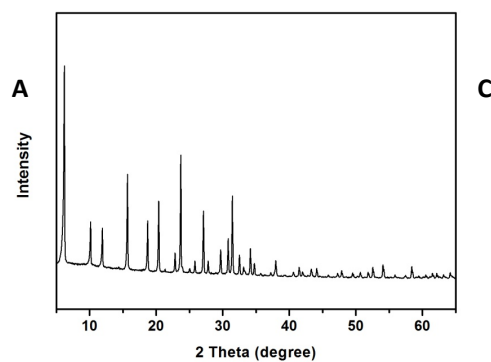

B

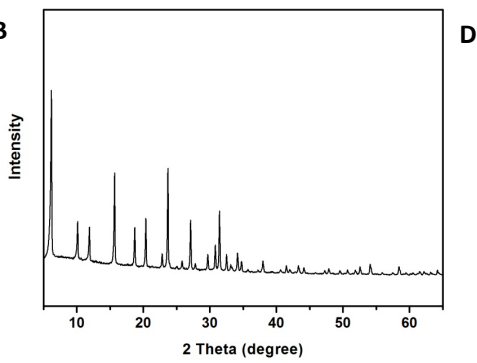

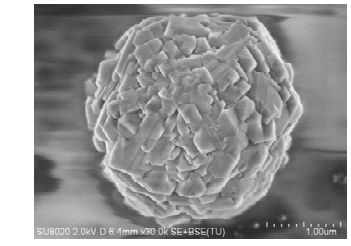

D

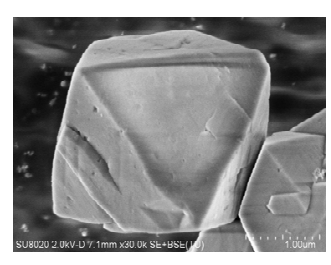

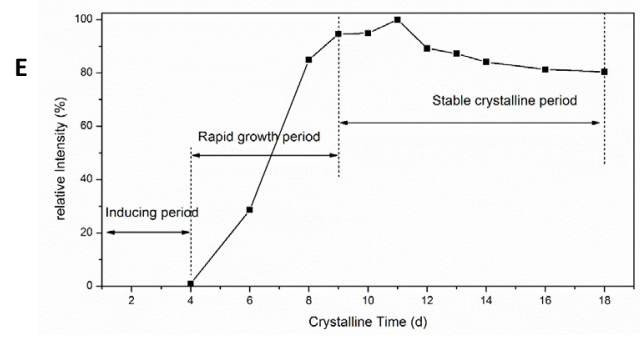

$\mathbf{F}$

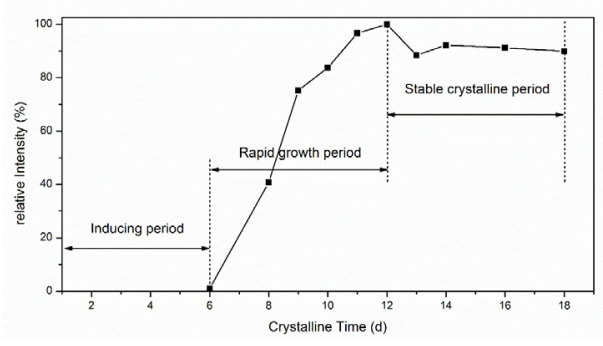

Fig. 1. XRD patterns of ChCl-Y (A) and ChOH-Y (B), SEM images of ChCl-Y (C) and ChOH-Y (D), and crystallization kinetic curves of ChCl-Y (E) and ChOH-Y (F). 
A

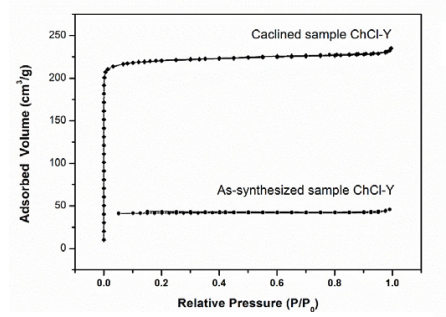

B

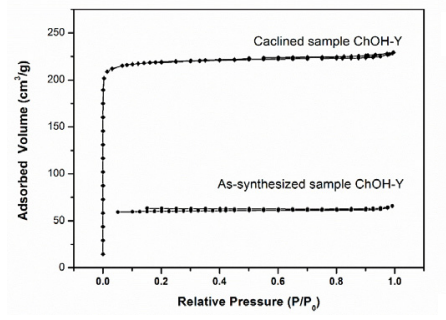

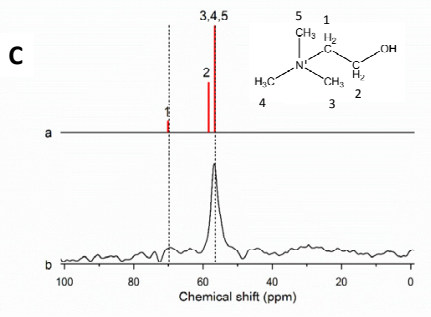

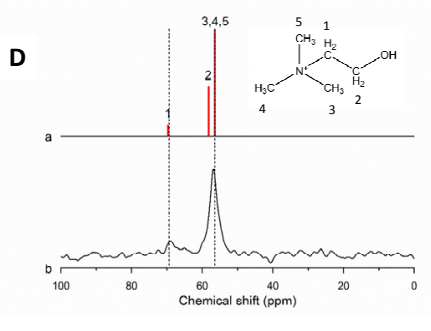

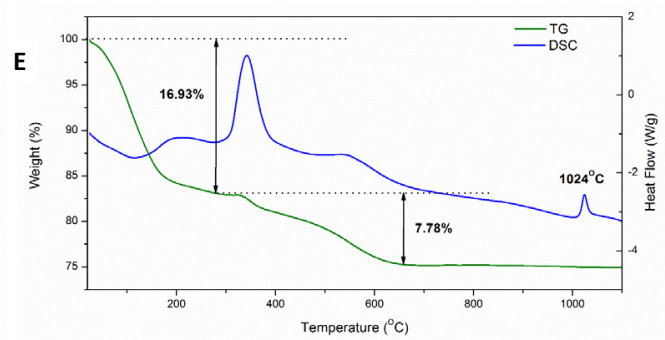

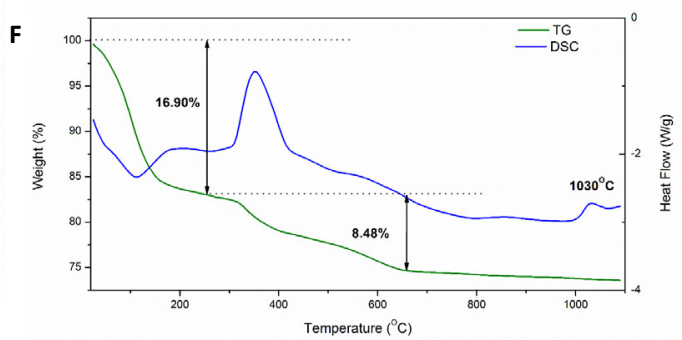

Fig. 2. $\mathrm{N}_{2}$ adsorption-desorption isotherms of the as-synthesized and calcined ChCl-Y (A) and ChOH-Y (B), ${ }^{13} \mathrm{C}$ NMR spectra (C) of choline (a) and ChCl-Y (b), ${ }^{13} \mathrm{C}$ NMR spectra (D) of choline (a) and ChOH-Y (b), and TG/DSC curves of ChCl-Y (E) and ChOH-Y (F).

the as-synthesized samples $\mathrm{ChCl-Y}$ and $\mathrm{ChOH}-\mathrm{Y}$ is much smaller than that of calcined ChCl-Y and ChOH-Y accordingly. Clearly, as-synthesized $\mathrm{ChCl}-\mathrm{Y}$ and $\mathrm{ChOH}-\mathrm{Y}$ undergo minimal adsorption, suggesting that the microporous structure is occupied with an amount of organic template. As-synthesized $\mathrm{ChCl}-\mathrm{Y}$ and ChOH-Y samples exhibit a similar ${ }^{13} \mathrm{C}-\mathrm{NMR}$ spectrum (Fig. $2 \mathrm{C}$ and Fig. 2D). There is a sharp peak appeared at $56.8 \mathrm{ppm}$ in both ${ }^{13} \mathrm{C}$ NMR spectra, which is specifically assigned to methyl groups nearby nitrogen atom in choline molecular. The peak shift at $68 \mathrm{ppm}$ is attributed to methoxy groups of choline. It is demonstrated that [choline] ${ }^{+}$acts as a structure-directing role in the synthesis of both ChCl-Y and ChOH-Y. The TG/DSC curves of as-synthesized ChCl-Y and ChOH-Y are shown in Fig. 2E and 2F. The TG/DSC results also prove that choline participates in the formulation of FAU framework as structure-directing agents. The endothermic weight loss at $100-300{ }^{\circ} \mathrm{C}$ is attributed to water desorption from samples. The water adsorption of $\mathrm{ChCl}-\mathrm{Y}$ and $\mathrm{ChOH}-\mathrm{Y}$ is respectively $16.93 \%$ and $16.90 \%$. The weight loss accompanied by raised exothermic peaks at $300-650{ }^{\circ} \mathrm{C}$ in $\mathrm{ChCl}-\mathrm{Y}$ and $\mathrm{ChOH}-\mathrm{Y}$ is respectively $7.78 \%$ and $8.48 \%$, which is attributed to the decomposition of organic templates. Carbon (C) and nitrogen (N) weight percentage of $\mathrm{ChCl}-\mathrm{Y}$ and $\mathrm{ChOH}-\mathrm{Y}$ is measured by elemental analysis (Table 1). The as-synthesized sample ChCl-Y contains $4.06 \mathrm{wt} \%$ carbon and $0.84 \mathrm{wt} \%$ nitrogen, which are obviously lower than $5.49 \mathrm{wt} \%$ carbon and $1.14 \mathrm{wt} \%$ nitrogen of $\mathrm{ChOH}-\mathrm{Y}$. The C/N molar ratios of both $\mathrm{ChCl}-\mathrm{Y}$ and $\mathrm{ChOH}-\mathrm{Y}$ are 5.6, close to that
(5.0) of $[\text { choline }]^{+}$(chemical formulae of [choline $]^{+}$: $\mathrm{C}_{5} \mathrm{H}_{13} \mathrm{OHN}^{+}$). It is also a powerful evidence that [choline] ${ }^{+}$acts as a structure-directing agent in the synthesis of high silica Y. The elemental analysis results of $\mathrm{Na}-\mathrm{Y}$ are set out in Table 1, suggesting that the organic content of $\mathrm{Na}-\mathrm{Y}$ is close to zero because $\mathrm{Na}-\mathrm{Y}$ is synthesized without any organic template. In Table 1, the $\mathrm{Na}_{2} \mathrm{O} / \mathrm{Al}_{2} \mathrm{O}_{3}$ ratios of ChCl-Y and ChOH-Y are respectively 0.83 and 0.74 , which are far smaller than that of $\mathrm{Na}-\mathrm{Y}(0.98)$ by XRF data. The ICP calculation results exhibit that the $\mathrm{Na}_{2} \mathrm{O} / \mathrm{Al}_{2} \mathrm{O}_{3}$ ratios of $\mathrm{ChCl}-\mathrm{Y}, \mathrm{ChOH}-\mathrm{Y}$ and $\mathrm{Na}-\mathrm{Y}$ are respectively $0.83,0.72$ and 1.01 , which are close to the XRF calculation. It is confirmed that [choline] ${ }^{+}$acts as a structuring-directing agent partially replacing $\mathrm{Na}^{+}$to occupy FAU supercages and compensate the negatively-charged Al framework sites. It is notable that carbon content of $\mathrm{ChCl}-\mathrm{Y}$ is less than that of $\mathrm{ChOH}-\mathrm{Y}$ and $\mathrm{Na}^{+}$content of $\mathrm{ChCl}-\mathrm{Y}$ is higher than that of $\mathrm{ChOH}-\mathrm{Y}$ in the contrary.

The ${ }^{27} \mathrm{Al}$ MAS-NMR and ${ }^{29} \mathrm{Si}$ MAS-NMR spectrograms of $\mathrm{ChCl}-\mathrm{Y}, \mathrm{ChOH}-\mathrm{Y}$ and Na-Y samples are presented in Fig. 3. They show almost the same ${ }^{27} \mathrm{Al}$ MAS-NMR spectrograms with only a sharp and symmetric peak centered at about $60 \mathrm{ppm}$, wich is indentified as tetrahedrally-coordinated framework aluminum, implying that the samples contain no octahedrally-coordinated aluminium of extra framework. The ${ }^{29} \mathrm{Si}$ MAS-NMR spectra of high silica $\mathrm{ChCl}-\mathrm{Y}$ and $\mathrm{ChOH}-\mathrm{Y}$ show that the $\mathrm{Si}(2 \mathrm{Al})$ peak is less intense but the $\mathrm{Si}(1 \mathrm{Al})$ and $\mathrm{Si}(0 \mathrm{Al})$ signals are more intense, compared to the corresponding signals of low silica $\mathrm{Na}-\mathrm{Y}$,

Table 1

The $\mathrm{SiO}_{2} / \mathrm{Al}_{2} \mathrm{O}_{3}$ ratios and $\mathrm{Na}_{2} \mathrm{O} / \mathrm{Al}_{2} \mathrm{O}_{3}$ ratios obtained by XRF, ${ }^{29} \mathrm{Si}-\mathrm{NMR}$ and ICP, and OSDA content of the as-synthesized products ChCl-Y, ChOH-Y, $\mathrm{ChCl} / \mathrm{ChOH}: 0.5 / 0.5-\mathrm{Y}$ and $\mathrm{Na}-\mathrm{Y}$.

\begin{tabular}{|c|c|c|c|c|c|c|c|c|}
\hline \multirow{2}{*}{ Sample } & \multicolumn{3}{|c|}{$\mathrm{SiO}_{2} / \mathrm{Al}_{2} \mathrm{O}_{3}$ molar ratio } & \multicolumn{2}{|c|}{$\mathrm{Na}_{2} \mathrm{O} / \mathrm{Al}_{2} \mathrm{O}_{3}$ molar ratio } & \multicolumn{3}{|c|}{ SDA content by elemental analysis } \\
\hline & XRF & ${ }^{29} \mathrm{Si}-\mathrm{NMR}$ & ICP & XRF & ICP & $\mathrm{C}(\mathrm{wt} \%)$ & $\mathrm{N}(\mathrm{wt} \%)$ & $\mathrm{C} / \mathrm{N}_{\text {ratio }}{ }^{3}$ \\
\hline $\mathrm{ChCl}-\mathrm{Y}$ & 6.46 & 6.34 & 6.48 & 0.83 & 0.83 & 4.06 & 0.84 & 5.6 \\
\hline $\mathrm{ChOH}-\mathrm{Y}$ & 6.78 & 6.54 & 6.83 & 0.74 & 0.72 & 5.49 & 1.14 & 5.6 \\
\hline $\mathrm{ChCl} / \mathrm{ChOH}: 0.5 / 0.5-\mathrm{Y}$ & 6.56 & 6.46 & 6.67 & 0.79 & 0.77 & 5.11 & 1.07 & 5.6 \\
\hline Na-Y & 5.56 & 5.40 & 5.50 & 0.98 & 1.01 & 0.24 & 0.07 & - \\
\hline
\end{tabular}

a The molar ratio of carbon to nitrogen calculated by elemental analysis. 

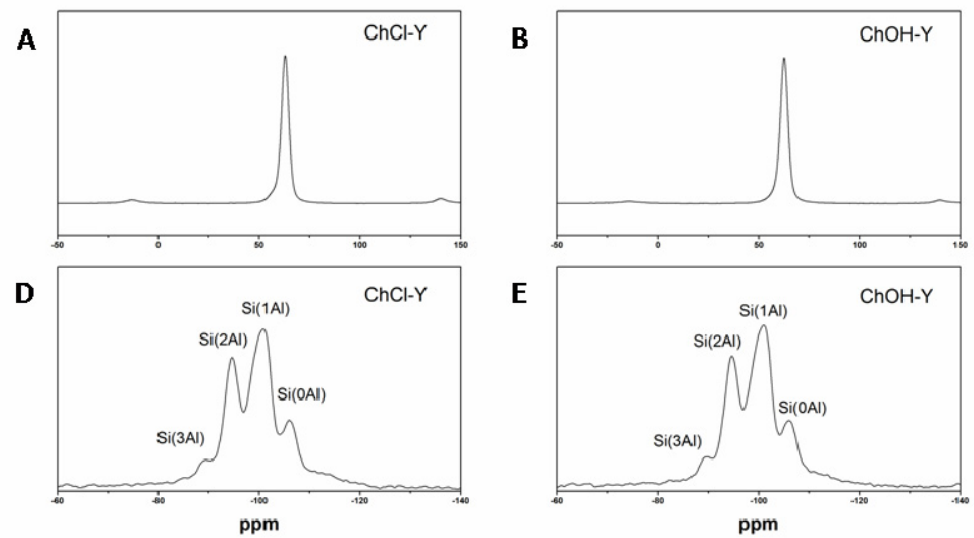

E
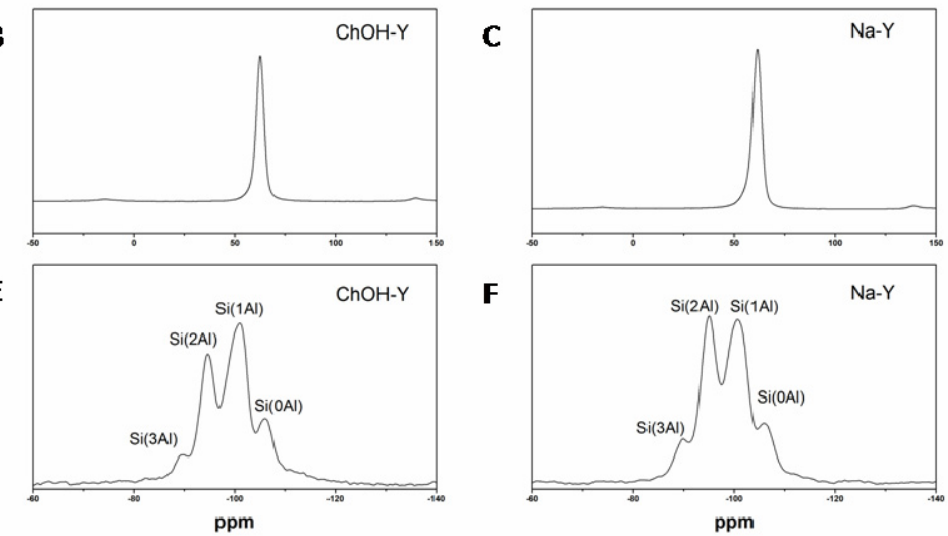

Fig. 3. ${ }^{27} \mathrm{Al}$ MAS-NMR spectrograms of (A) ChCl-Y, (B) ChOH-Y and (C) Na-Y, and ${ }^{29} \mathrm{Si}$ MAS-NMR spectrograms of (D) ChCl-Y, (E) ChOH-Y and (F) Na-Y.

wherein $\mathrm{Si}(n \mathrm{Al})$ represents that one $\mathrm{Si}$ atom connects to $n \mathrm{Al}$ atoms and $(4-n)$ Si atoms in the second coordination shell by a bridging oxygen. The results indicate that choline as an OSDA could decrease the number of framework aluminium atoms per unit cell and increase the framework $\mathrm{SiO}_{2} / \mathrm{Al}_{2} \mathrm{O}_{3}$ ratio, which has been certified the calculation by XRF and ICP methods.

The $\mathrm{SiO}_{2} / \mathrm{Al}_{2} \mathrm{O}_{3}$ ratio of the three products $\mathrm{ChOH}-\mathrm{Y}, \mathrm{ChCl}-\mathrm{Y}$ and Na-Y presented in Table 1 are calculated by XRF, ${ }^{29} \mathrm{Si}-\mathrm{NMR}$ and ICP. The XRF data indicate that $\mathrm{ChCl}-\mathrm{Y}$ and $\mathrm{ChOH}-\mathrm{Y}$ have higher $\mathrm{SiO}_{2} / \mathrm{Al}_{2} \mathrm{O}_{3}$ ratios of 6.46 and 6.78 , which are much higher than that (5.56) of Na-Y zeolites with the traditional synthesis method. It could be explained by the theory that relatively larger organic cations ([choline $\left.]^{+}\right)$with a lower charge density introduce a lower number of positive charges than small inorganic cations $\left(\mathrm{Na}^{+}\right)$within the zeolite cages, thus matching a lower number of framework $\mathrm{Al}$ atoms with negative charges, and increasing the framework $\mathrm{SiO}_{2} / \mathrm{Al}_{2} \mathrm{O}_{3}$ ratio. $\mathrm{ChCl}-\mathrm{Y}$ and $\mathrm{ChOH}-\mathrm{Y}$ have $\mathrm{SiO}_{2} / \mathrm{Al}_{2} \mathrm{O}_{3}$ ratios of 6.48 and 6.83 obtained by ICP analysis, which is in agreement with XRF calculation. The ${ }^{29} \mathrm{Si}$ NMR spectroscopy is also used as an accurate characterization measuring the framework $\mathrm{SiO}_{2} / \mathrm{Al}_{2} \mathrm{O}_{3}$ ratio. The $\mathrm{SiO}_{2} / \mathrm{Al}_{2} \mathrm{O}_{3}$ ratios of the samples are calculated with the signals of $\mathrm{Si}(n \mathrm{Al})$ species $(n=0-3)$ in Fig. 3. The framework $\mathrm{SiO}_{2} / \mathrm{Al}_{2} \mathrm{O}_{3}$ ratios of $\mathrm{ChCl}-\mathrm{Y}$ and $\mathrm{ChOH}-\mathrm{Y}$ are respectively 6.34 and 6.54, whereas the $\mathrm{SiO}_{2} / \mathrm{Al}_{2} \mathrm{O}_{3}$ ratio of $\mathrm{Na}-\mathrm{Y}$ is only 5.4 , far below the framework $\mathrm{SiO}_{2} / \mathrm{Al}_{2} \mathrm{O}_{3}$ ratios of $\mathrm{ChCl}-\mathrm{Y}$ and $\mathrm{ChOH}-\mathrm{Y}$. The ${ }^{29} \mathrm{Si}$ NMR results are slightly lower than those obtained by XRF and ICP, which could be explained by the presence of partial Al sites substituted by terminal $\mathrm{OH}$ species in the framework, decreasing the data calculated by the ${ }^{29} \mathrm{Si}-\mathrm{NMR}$ spectrum. It is a great breakthrough that high silica zeolite $\mathrm{Y}$ could be synthesized with choline as a low-cost and eco-friendly organic template. Even more remarkable, $\mathrm{ChOH}-\mathrm{Y}$ has a higher $\mathrm{SiO}_{2} / \mathrm{Al}_{2} \mathrm{O}_{3}$ ratio than ChCl-Y.

\subsection{Synthesis design and characterization of ChCl/ChOH:0.5/0.5-Y and other samples}

It arouses our interest that not only ChCl-Y and ChOH-Y exhibit entirely different crystal morphologies, but also the choice of choline chloride and choline hydroxide has a great influence on the framework $\mathrm{SiO}_{2} / \mathrm{Al}_{2} \mathrm{O}_{3}$ ratio. This gives us a brand new idea how to increase $\mathrm{SiO}_{2} / \mathrm{Al}_{2} \mathrm{O}_{3}$ ratio of $\mathrm{Y}$ zeolite, and impels us to further investigate the roles and relationship of [choline] ${ }^{+}$ and $\mathrm{Na}^{+}$in the synthesis of zeolite $\mathrm{Y}$ with OSDAs. As discussed in the previous part, the physicochemical differences of $\mathrm{ChCl}-\mathrm{Y}$ and $\mathrm{ChOH}-\mathrm{Y}$ are caused by the various feed molar ratio of $\mathrm{Na}^{+}$ in the starting gels. In general, alkali-metal cations $\left(\mathrm{Na}^{+}\right)$play two roles in the synthesis of zeolite, acting as (i) a source of alkalinity ( $\mathrm{NaOH}$ is commonly used in Y zeolite synthesis) and (ii) a limited structure-directing agent [2]. [choline]+ has been confirmed to be a structure-directing agent in the synthesis process of both $\mathrm{ChCl}-\mathrm{Y}$ and $\mathrm{ChOH}-\mathrm{Y}$, but only choline hydroxide can be used as the source of alkalinity. Therefore choline hydroxide could provide sufficient alkalinity in the synthesis of $\mathrm{ChOH}-\mathrm{Y}$, use only half the amount of raw material $\mathrm{NaOH}$ during the synthesis of $\mathrm{ChCl}-\mathrm{Y}$, and sharply decrease the feedstock amount of $\mathrm{Na}^{+}$(nearly one third). Based on the asNa+sumption that the differences of $\mathrm{ChCl}-\mathrm{Y}$ and $\mathrm{ChOH}-\mathrm{Y}$ are caused by the variation of $\mathrm{Na}^{+}$feed ratio, a typical sample $\mathrm{ChCl} / \mathrm{ChOH}: 0.5 / 0.5-\mathrm{Y}$ is designed with the $\mathrm{Na}^{+} / \mathrm{SiO}_{2}$ feed molar ratio (0.5) between that of ChCl-Y (0.6) and ChOH-Y (0.4). The synthetic methodology is rationally designed with the same [choline] ${ }^{+}$and $\mathrm{OH}^{-}$concentration as $\mathrm{ChCl}-\mathrm{Y}$ and $\mathrm{ChOH}-\mathrm{Y}$ by changing $\mathrm{ChOH} / \mathrm{NaOH}$ ratio. The corresponding XRD pattern shows that $\mathrm{ChCl} / \mathrm{ChOH}: 0.5 / 0.5-\mathrm{Y}$ has FAU topological structure with good crystallization (Fig. 4A). The SEM image (Fig. 4B) shows uniform irregular polyhedron, which is different with the morphology of both $\mathrm{ChCl}-\mathrm{Y}$ and $\mathrm{ChOH}-\mathrm{Y}$. Therefore, the change of $\mathrm{Na}^{+}$feed molar ratio has a decisive influence on the crystal morphology. Comparing the $\mathrm{SiO}_{2} / \mathrm{Al}_{2} \mathrm{O}_{3}$ ratio,
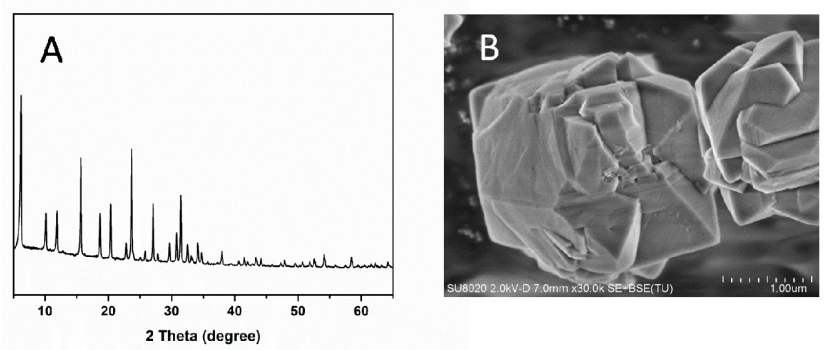

Fig. 4. XRD pattern (A) and SEM image (B) of $\mathrm{ChCl} / \mathrm{ChOH}: 0.5 / 0.5-\mathrm{Y}$. 

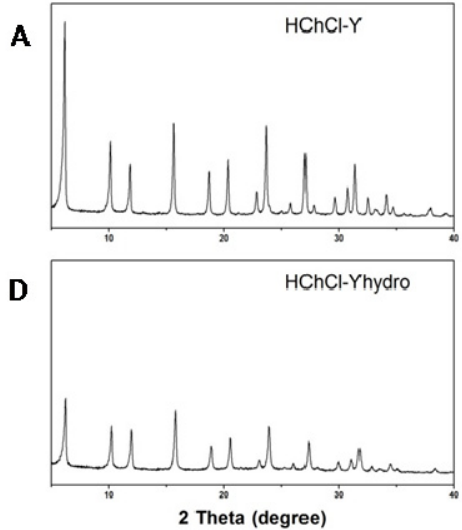

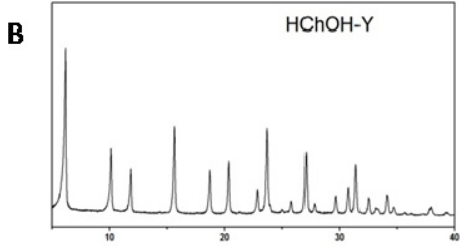

E

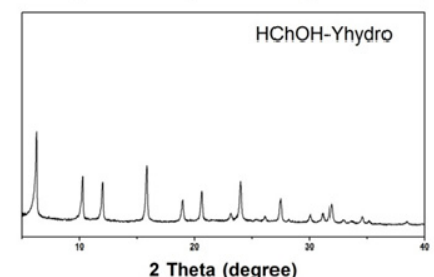

C

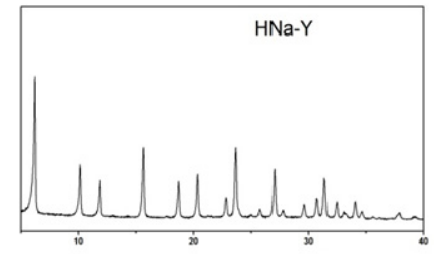

F

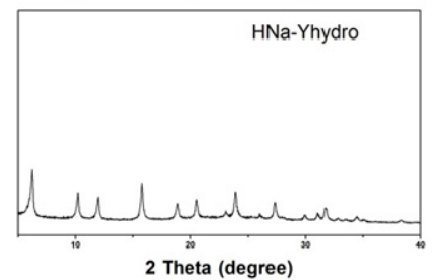

Fig. 5. XRD patterns of HChCl-Y (A), HChOH-Y (B), HNa-Y (C), HChCl-Yhydro (D), HChOH-Yhydro (E) and HNa-Yhydro (F). HChCl-Yhydro, $\mathrm{HChOH}-Y$ hydro and HNa-Yhydro are respectively corresponded to $\mathrm{HChCl}-\mathrm{Y}, \mathrm{HChOH}-\mathrm{Y}$ and $\mathrm{HNa}-\mathrm{Y}$ after $100 \%$ steam treatment at $750{ }^{\circ} \mathrm{C}$ for $2 \mathrm{~h}$.

$\mathrm{Na}_{2} \mathrm{O} / \mathrm{Al}_{2} \mathrm{O}_{3}$ ratio and OSDA content in Table 1 , it is obviously shown a regular variation of the final products: as the $\mathrm{Na}^{+} / \mathrm{SiO}_{2}$ feed molar fraction (0.6, 0.5 and 0.4 corresponding to $\mathrm{ChCl}-\mathrm{Y}$, $\mathrm{ChCl} / \mathrm{ChOH}: 0.5 / 0.5-\mathrm{Y}$ and $\mathrm{ChOH}-\mathrm{Y}$ ) in their starting gels reduces, the $\mathrm{SiO}_{2} / \mathrm{Al}_{2} \mathrm{O}_{3}$ ratio increased $(6.48,6.67$ and 6.83 by ICP), the $\mathrm{Na}_{2} \mathrm{O} / \mathrm{Al}_{2} \mathrm{O}_{3}$ ratio decreased $(0.72,0.77$ and 0.83 by ICP), and OSDA content raised accordingly (C \%: 4.06\%, 5.11\% and $5.49 \%$ by elemental analysis). In the final liquid-solid mixture, a part of [choline] ${ }^{+}$and $\mathrm{Na}^{+}$dissociate in the solution, and the other part of them fill in the micropores. There is inevitably a competition between $\mathrm{Na}^{+}$and [choline] ${ }^{+}$acting as structure-directing agents and skeletal fillers in the synthesis of Y zeolite. The results demonstrate that the molar ratio of $\mathrm{Na}^{+}$to [choline] ${ }^{+}$is a crucial factor for their competition and further influences the framework $\mathrm{SiO}_{2} / \mathrm{Al}_{2} \mathrm{O}_{3}$ ratio. The use of OSDAs in a $\mathrm{OH}^{-}$form is a direct and efficient method to enhance the framework $\mathrm{SiO}_{2} / \mathrm{Al}_{2} \mathrm{O}_{3}$ ratio, which reduces the feedstock amount of $\mathrm{Na}^{+}$to weaken the competiveness of $\mathrm{Na}^{+}$. However, when the feed of $\mathrm{Na}^{+}$is reduced below 0.3 , it is difficult to form uniform zeolite $\mathrm{Y}$; the result accompanies lots of amorphous aluminosilicate (samples \#1 and \#2 in Table S2, Fig. S2 and Fig. S3). A certain amount of $\mathrm{Na}^{+}$is an essential part of the synthesis of Y zeolite.

Normally, zeolite $\mathrm{Y}$ is synthesized at $100{ }^{\circ} \mathrm{C}$ with high alkalinity as the sample $\mathrm{Na}-\mathrm{Y}$. ChCl-Y and $\mathrm{ChOH}-\mathrm{Y}$ are designed with low alkalinity at $110{ }^{\circ} \mathrm{C}$ because the low alkalinity and high crystallization temperature during the synthesis are helpful for enhancing the $\mathrm{SiO}_{2} / \mathrm{Al}_{2} \mathrm{O}_{3}$ ratio of the final zeolites. However, when the temperature is increased to $120^{\circ} \mathrm{C}$, the same aluminosilicate gel produces FAU and MAZ zeolite (samples \#3 and \#4 in Table S2, Fig. S4 and Fig. S5). When the feed molar fraction of choline cation is increased to 2.0 , it is plainly a tendency that the final products transform from the FAU topology to MAZ structure (sample \#5 in Table S2 and Fig. S6). Choline is also used as an OSDA for synthesizing zeolite ZSM-4 with MAZ framework [34].

\subsection{Hydrothermal and thermal stability of ChCl-Y, $\mathrm{ChOH}-\mathrm{Y}$ and $\mathrm{Na}-\mathrm{Y}$}

It is well known that the (hydro)thermal stability of zeolite at high temperature has a strong relationship with the framework $\mathrm{SiO}_{2} / \mathrm{Al}_{2} \mathrm{O}_{3}$ ratio, which is a crucial factor for industrial applications. The exothermic peaks without weight variation above $800{ }^{\circ} \mathrm{C}$ in the TG/DSC curves are attributed to the structural collapse of zeolite $\mathrm{Y}$, which is used as a main evaluation of the thermal stability of zeolites at high temperature. Na-Y starts to collapse at $970{ }^{\circ} \mathrm{C}$ (Fig. S7), but the skeleton of $\mathrm{ChCl}-\mathrm{Y}$ and $\mathrm{ChOH}-\mathrm{Y}$ remains stable until 1024 and $1030{ }^{\circ} \mathrm{C}$ (Fig. 2E and 2F). The results are also additional evidence that our materials have unusually ultrahigh $\mathrm{SiO}_{2} / \mathrm{Al}_{2} \mathrm{O}_{3}$ ratio. The crystallinity change before and after steam treatment at high temperature is a measure of the hydrothermal stability of zeolites. The XRD patterns of $\mathrm{HChCl}-\mathrm{Y}, \mathrm{HChOH}-\mathrm{Y}$ and HNa-Y (the correspond H-form samples after ammonium ion exchange and calcination) before and after $100 \%$ steam treatment at $750{ }^{\circ} \mathrm{C}$ for $2 \mathrm{~h}$ are shown in

Table 2

Textural properties of $\mathrm{HChCl}-\mathrm{Y}, \mathrm{HChOH}-\mathrm{Y}$ and $\mathrm{HNaY}$ samples before and after the hydrothermal treatment by $100 \%$ steam at $750{ }^{\circ} \mathrm{C}$ for $2 \mathrm{~h}$.

\begin{tabular}{lccc}
\hline Sample & $\begin{array}{c}\text { Relative crystallinity } \\
(\%)\end{array}$ & $\begin{array}{c}\text { BET specific surface area } \\
\left(\mathrm{m}^{2} / \mathrm{g}\right)\end{array}$ & $\begin{array}{c}t \text {-Plot micropore surface area } \\
\left(\mathrm{m}^{2} / \mathrm{g}\right)\end{array}$ \\
\hline HChCl-Y & 100 & 677.3 & 617.4 \\
HChOH-Y & 100 & 690.9 & 624.2 \\
HNa-Y & 100 & 535.4 & 490.8 \\
HChCl-Yhydro & 56.6 & 412.3 & 318.0 \\
HChOH-Yhydro & 54.2 & 507.5 & 418.6 \\
HNa-Yhydro & 38.5 & 352.4 & 30.0 \\
\hline
\end{tabular}

a Estimated by the reflection intensities of the X-ray diffraction peaks (1 1 1), (2 2 0) and (3 3 1) of the samples. 
Fig. 5. This indicates that the crystallinity of HNa-Y descents more steeply than that of $\mathrm{HChCl}-\mathrm{Y}$ and $\mathrm{HChOH}-\mathrm{Y}$ after steam treatment. The crystallinity of $\mathrm{HChCl}-\mathrm{Y}$ and $\mathrm{HChOH}-\mathrm{Y}$ retains $54.2 \%$ and $56.6 \%$, higher than $38.5 \%$ of HNa-Y; BET specific surface area and $t$-plot micropore surface area of HNa-Y are obviously lower than that of $\mathrm{HChCl}-\mathrm{Y}$ and $\mathrm{HChOH}-\mathrm{Y}$ after steam treatment (Table 2). The results indicate that $\mathrm{ChCl}-\mathrm{Y}$ and ChOH-Y exhibit a more superior hydrothermal and thermal stability owing to the higher framework $\mathrm{SiO}_{2} / \mathrm{Al}_{2} \mathrm{O}_{3}$ ratio. It is known that the bond energy of the silicon-oxygen bond ( $\mathrm{Si}-\mathrm{O}-\mathrm{Si}$ ) is higher than that of the aluminium-oxygen bond (Al-O-Si), so the $\mathrm{Si}-\mathrm{O}-\mathrm{Si}$ bond is more stable than the $\mathrm{Al}-\mathrm{O}-\mathrm{Si}$ bond. $\mathrm{ChCl}-\mathrm{Y}$ and $\mathrm{ChOH}-\mathrm{Y}$ have higher $\mathrm{Si}-\mathrm{O}-\mathrm{Si} / \mathrm{Al}-\mathrm{O}-\mathrm{Si}$ ratio than $\mathrm{Na}-\mathrm{Y}$, which has been interpreted with the ${ }^{29} \mathrm{Si}-\mathrm{NMR}$ spectrum (Fig. 4). Collectively, these studies confirm the practical advantages of increasing $\mathrm{Y}$ zeolite $\mathrm{SiO}_{2} / \mathrm{Al}_{2} \mathrm{O}_{3}$ ratio to improve the (hydro)thermal stability, which enhances the adaptation of Y zeolite for catalytic applications.

\section{Conclusions}

A FAU zeolite with good crystallinity has been synthesized with the use of choline as an eco-friendly and biodegradable OSDA for the first time. The synthetic samples $\mathrm{ChCl}-\mathrm{Y}$ and $\mathrm{ChOH}-\mathrm{Y}$ have $\mathrm{SiO}_{2} / \mathrm{Al}_{2} \mathrm{O}_{3}$ ratios of 6.48 and 6.83 , which are much higher than that of common $\mathrm{Y}$ zeolite prepared by OSDA-free routes. Both $\mathrm{ChCl}-\mathrm{Y}$ and $\mathrm{ChOH}-\mathrm{Y}$ exhibit outstanding thermal and hydrothermal stability owing to higher $\mathrm{SiO}_{2} / \mathrm{Al}_{2} \mathrm{O}_{3}$ ratio. Based on a thoughtful experiment design, it is proved that $\mathrm{Na}^{+}$show a seemingly stronger competitiveness than [choline]+ in the cage of FAU zeolite and the feed fraction of $\mathrm{Na}^{+}$has a crucial influence on the FAU framework $\mathrm{SiO}_{2} / \mathrm{Al}_{2} \mathrm{O}_{3}$ ratio. The use of OSDAs with $\mathrm{OH}^{-}$anion enhancing the zeolite $\mathrm{SiO}_{2} / \mathrm{Al}_{2} \mathrm{O}_{3}$ ratio is a valued inspiration for the synthesis of high silica zeo- lite. These unique findings are of potential importance for the future industrial application of high silica FAU zeolite as an adsorbent and a catalyst.

\section{References}

[1] R. M. Barrer, Zeolites, 1981, 1, 130-140.

[2] M. E. Davis, R. F. Lobo, Chem. Mater., 1992, 4, 756-768.

[3] M. E. Davis, Nature, 2002, 417, 813-821.

[4] A. Corma, J. Catal., 2003, 216, 298-312.

[5] W. Vermeiren, J. P. Gilson, Top. Catal., 2009, 52, 1131-1161.

[6] G. T. Kerr, G. T. Kokotailo, J. Am. Chem. Soc., 1961, 83, 4675.

[7] C. S. Cundy, P. A. Cox, Chem. Rev., 2003, 103, 663-702.

[8] L. A. Villaescusa, W. Zhou, R. E. Morris, P. A. Barrett, J. Mater. Chem., 2004, 14, 1982-1987.

[9] X. Meng, F. S. Xiao, Chem. Rev., 2014, 114, 1521-1543.

[10] L. Ren, L. Zhu, C. Yang, Y. Chen, Q. Sun, H. Zhang, C. Li, F. Nawaz, X. Meng, F. S. Xiao, Chem. Commun., 2011, 47, 9789-9791.

[11] S. I. Zones, S. J. Hwang, Chem. Mater., 2002, 14, 313-320.

[12] S. Liu, L. Li, C. Li, X. Xiong, F. S. Xiao, J. Porous Mater., 2008, 15, 295-301.

[13] D. W. Breck, US Patent, 3130007A, 1964.

[14] P. K. Maher, E. W. Albers, C. V. McDaniel, US Patent, 3639099A, 1972.

[15] J. P. Arhancet, M. E. Davis, Chem. Mater., 1991, 3, 567-569.

[16] S. M. Babitz, B. A. Williams, J. T. Miller, R. Q. Snurr, W. Q. Haag, H. H. Kung, Appl. Catal., A, 1999, 179, 71-86.

[17] M. A. Camblor, A. Corma, A. Martínez, F. A. Mocholí, J. P. Pariente, Appl. Catal., 1989, 55, 65-74.

[18] E. F. S. Aguiar, M. L. M. Valle, M. P. Silva, D. F. Silva, Zeolites, 1995, $15,620-623$.

[19] R. A. Beyerlein, G. B. McVicker, L. N. Yacullo, J. J. Ziemiak, J. Phys. Chem., 1988, 92, 1967-1970.

[20] B. Xu, S. Bordiga, R. Prins, J. A. van Bokhoven, Appl. Catal. A, 2007, 333, 245-253.

[21] M. D. Oleksiak, K. Muraoka, M. F. Hsieh, M. T. Conato, A. Shimojima, T. Okubo, W. Chaikittisilp, J. D. Rimer, Angew. Chem. Int. Ed., 2017,

\section{Graphical Abstract}

Chin. J. Catal., 2019, 40: 52-59 doi: 10.1016/S1872-2067(18)63167-5

\section{Eco-friendly synthesis of high silica zeolite $Y$ with choline as green and innocent structure-directing agent}

Dawei He, Danhua Yuan, Zhijia Song, Yunpeng Xu*, Zhongmin Liu*

Dalian Institute of Chemical Physics, Chinese Academy of Sciences; University of Chinese Academy of Sciences

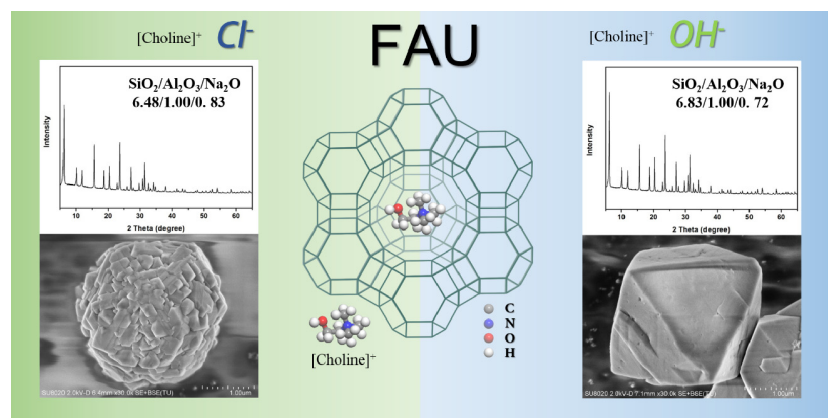

Choline chloride or choline hydroxide was used as an eco-friendly and nontoxic organic structure-directing agent (OSDA) for the synthesis of high silica zeolite $\mathrm{Y}$ with $\mathrm{SiO}_{2} / \mathrm{Al}_{2} \mathrm{O}_{3}$ ratios of 6.5-6.8. 
56, 13366-13371.

[22] L. Kubelková, S. Beran, A. Malecka, V. M. Mastikhin, Zeolites, 1989, 9, 12-17.

[23] G. Garralon, V. Fornes, A. Corma, Zeolites, 1988, 8, 268-272.

[24] J. Datka, W. Kolidziejski, J. Klinowski, B. Sulikowski, Catal. Lett., 1993, 19, 159-165.

[25] E. F. T. Lee, L. V. C. Rees, J. Chem. Soc., Faraday Trans. 1, 1987, 83, 1531-1537.

[26] X. H. Du, X. L. Li, H. T. Zhang, X. H. Gao, Chin. J. Catal., 2016, 37, 316-323.

[27] F. Delprato, L. Delmotte, J. L. Guth, L. Huve, Zeolites, 1990, 10, 546-552.

[28] F. Dougnier, J. Patarin, J. L. Guth, D. Anglerot, Zeolites, 1993, 13, 122-127.

[29] L. Zhu, L. Ren, S. Zeng, C. Yang, H. Zhang, X. Meng, M. Rigutto, A. van der Made, F. S. Xiao, Chem. Commun., 2013, 49, 10495-10497.

[30] D. Yuan, D. He, S. Xu, Z. Song, M. Zhang, Y. Wei, Y. He, S. Xu, Z. Liu, Y. Xu, Microporous Mesoporous Mater., 2015, 204, 1-7.
[31] D. He, D. Yuan, Z. Song, Y. Tong, Y. Wu, S. Xu, Y. Xu, Z. Liu, Chem. Commun., 2016, 52, 12765-12768.

[32] S. H. Zeisel, Ann. Nutr. Metab., 2012, 61, 254-258.

[33] F. Liu, M. Audemar, K. De Oliveira Vigier, D. Cartigny, J. M. Clacens, M. F. C. Gomes, A. A. H. Padua, F. De Campo, F. Jerome, Green Chem., 2013, 15, 3205-3213.

[34] A. J. Perrotta, C. Kibby, B. R. Mitchell, E. R. Tucci, J. Catal., 1978, 55, 240-249.

[35] B. Chen, R. Xu, R. Zhang, N. Liu, Environ. Sci. Technol., 2014, 48, 13909-13916.

[36] X. Zhao, H. Wang, C. Kang, Z. Sun, G. Li, X. Wang, Microporous Mesoporous Mater., 2012, 151, 501-505.

[37] A. I. Lupulescu, J. D. Rimer, Angew. Chem. Int. Ed., 2012, 51, 3345-3349.

[38] A. I. Lupulescu, M. Kumar, J. D. Rimer, J. Am. Chem. Soc., 2013, 135, 6608-6617.

[39] A. Burton, Catal. Rev.-Sci. Eng., 2018, 60, 132-175.

\title{
以胆碱为绿色无毒有机结构导向剂合成高硅Y型分子篮
}

\author{
贺大威 $\mathrm{a}, \mathrm{b}, \dagger$ ，袁丹华 ${ }^{\mathrm{a}, \dagger}$ ，宋智甲 ${ }^{\mathrm{a}, \mathrm{b}}$ ，徐云鹏 ${ }^{\mathrm{a},{ }^{*}}$ ，刘中民 ${ }^{\mathrm{a}, \#}$ \\ a 中国科学院大连化学物理研究所洁净能源国家实验室(筹), 甲醇制烯烃国家工程实验室, 辽宁大连 116023 \\ b中国科学院大学, 北京100049
}

\begin{abstract}
摘要: 分子笁作为一类重要的无机多孔晶体材料, 由于其规整的孔道结构以及优异的酸性质等特点, 在催化剂、吸附剂和 离子交换床等许多领域有着重要而广泛的应用. 而现代分子篮制备方法的发展主要得益于有机结构导向剂(OSDA)在分子 筛合成中的广泛使用. 但是, 大部分OSDA都具有剧毒、价格昂贵、制备方法繁琐等缺点, 因而限制了其大规模应用. 高硅 Y型分子篮的合成研究也面临同样的问题.

Y型分子篮具有十二元环孔口和三维孔道结构, 是目前催化裂化催化剂中的主要活性组分. 目前, 通过常规合成方法 无法获得硅铝比大于 6.0 的Y型分子篎, 无法满足石油化工对其酸性的要求. 目前工业上主要通过后处理法得到高硅Y沸石, 但该方法繁杂的后处理过程、不均匀的化学分布、大量损失的结晶度以及严重的环境污染促使人们开发直接合成高硅Y 型分子篮的新方法以替代后处理过程. 此外, 使用OSDA一步法合成的高硅铝比Y型分子篮具有优异的热和水热稳定性. 因此, 使用OSDA一步直接合成高硅Y型分子篮在材料合成和催化领域一直备受关注. 然而, 目前尚未见关于绿色OSDA用 于高硅Y型分子篮合成的报道.

本研究首次将氢氧化胆碱或氯化胆碱作为一种新型、绿色、廉价的OSDA引入到高硅Y分子篎的合成凝胶体系, 成功 合成了高结晶度且硅铝比大于 6.0 的高硅 $Y$ 型分子篮. 实验详细考察了合成条件对硅铝比的影响, 并采用XRD, XRF, NMR, TG以及 $\mathrm{N}_{2}$ 物理吸附等表征手段研究了合成样品的物理化学性质. 表征结果证明, 胆碱阳离子作为一个稳定的OSDA存在 于分子篮的孔结构中, 并且取代了部分 $\mathrm{Na}^{+}$以平衡分子筛骨架的负电荷, 因此胆碱的使用可使样品的硅铝比提高并具有更 加优异的热稳定性和水热稳定性. 实验确定了 $\mathrm{Na}^{+}$和OSDA 在高硅Y分子篮合成中的竞争关系. 大量的实验证据表明, $\mathrm{Na}^{+}$ 进料比例对FAU骨架硅铝比有决定性的影响. 首次提出采用氢氧根离子型OSDA是一种直接有效提高骨架硅铝比的方法. 关键词: 分子篎合成; FAU分子篎; 高硅铝比; 绿色有机结构导向剂; (水)热稳定性
\end{abstract}

收稿日期: 2018-09-12. 接受日期: 2018-09-23. 出版日期: 2019-01-05.

†共同第一作者.

*通讯联系人. 电话: (0411)84379518; 传真: (0411)84379038; 电子信箱: xuyp@dicp.ac.cn

\#通讯联系人. 电话: (0411)84379998; 传真: (0411)84379038; 电子信箱: liuzm@dicp.ac.cn

基金来源: 国家自然科学基金(21802136).

本文的电子版全文由Elsevier出版社在ScienceDirect上出版(http://www.sciencedirect.com/science/journal/18722067). 